\author{
JACEK HADRYŚ \\ Uniwersytet im. Adama Mickiewicza w Poznaniu \\ Wydział Teologiczny
}

\title{
Duchowość ekologiczna w świetle Laudato si' papieża Franciszka
}

Ecological Spirituality in the Light of Laudato si' of Pope Francis

Duchowość można określić jako konkretną realizację komunii człowieka z Bogiem, którą w chrześcijaństwie utożsamia się z życiem wewnętrznym, życiem duchowym. Hans Urs von Balthasar określił ją jako konkretną formę świętości, realizowaną przez wiernych w zależności od warunków, w jakich żyją. Badając życie duchowe chrześcijanina, niejednokrotnie można zauważyć jakąś prawdę wiary bądź praktykę ascetyczną czy duchową, która w dążeniu do komunii z Bogiem jest bardziej akcentowana, stając się wyraźnym rysem egzystencjalnym. Mówi się wówczas o tzw. duchowości szczegółowej, np. eucharystycznej, maryjnej, ekumenicznej, pokutnej czy misyjnej ${ }^{1}$. W tym kontekście duchowość ekologiczna będzie mocno podkreślała relacje ze światem jako wyraźną realizację komunii człowieka z Bogiem; innymi słowy, to forma realizowania świętości szczególnie uwzględniająca i akcentująca relacje ze światem. Stąd chrześcijanin charakteryzujący się duchowością ekologiczną w swoim dążeniu do świętości będzie kładł nacisk na wszystkie konsekwencje spotkania człowieka z Jezusem w relacjach z otaczającym go światem. Papież Franciszek edukacji i duchowości ekologicznej poświęcił ostatni, szósty rozdział encykliki Laudato si'. Jednak wszechstronne przedstawienie i zrozumienie ekologicznej duchowości wymaga przeanalizowania całego papieskiego dokumentu. Artykuł omawiający wspomniane zagadnienie został podzielony na dwie części. W pierwszej z nich wskazano na biblijne oraz teologiczno-praktyczne przesłanki i uzasadnienia potrzeby duchowości ekologicznej, w drugiej natomiast przedstawiono jej owoce i konse-

${ }^{1}$ Zob. J. Gogola, Teologia komunii z Bogiem, Kraków 2003, s. 17-21; J. Hadryś, A B C... życia duchowego w pytaniach i odpowiedziach, Poznań 2009, s. 11-12. 
kwencje. W posumowaniu badań ukazano znaczenie duchowości ekologicznej dla dobra i bezpieczeństwa człowieka.

\section{BIBLIJNE ORAZ TEOLOGICZNO-PRAKTYCZNE PRZESŁANKI UZASADNIAJACE POTRZEBĘ I WARTOŚĆ DUCHOWOŚCI EKOLOGICZNEJ}

\section{Przesłanki biblijne}

Papież Franciszek, aby uzasadnić potrzebę i wartość duchowości ekologicznej, sięgnął do Biblii. Powołując się na biblijne opisy stworzenia świata, zauważył, że mówiąc o relacji między człowiekiem a otaczającym go światem, trzeba podkreślić ogromną godność każdej ludzkiej osoby, która jest zdolna do poznawania siebie, panowania nad soba, miłowania i tworzenia relacji z innymi (por. LS 65$)^{2}$. Zdaniem Franciszka, biblijne opisy stworzenia sugerują że ludzka egzystencja opiera się na trzech podstawowych relacjach, które są ze sobą ściśle powiązane: na relacji z Bogiem, innymi ludźmi oraz ziemią (por. LS 66). Według Ojca Świętego człowiek powinien bronić, chronić, strzec otaczający go świat i troszczyć się o niego. Tak bowiem należy rozumieć obowiązek panowania nad ziemią, który otrzymał od Stwórcy (LS 67) ${ }^{3}$. O takim rozumieniu wspomnianego nakazu mówi również - zdaniem papieża - niepodważalny fakt, że ziemia jest własnością Boga, nie człowieka, który ją niejako dzierżawi, a więc ponosi za nią odpowiedzialność (por. LS 67) ${ }^{4}$. Papież Franciszek, powołując się na fragmenty ze Starego Testamentu, przypomniał słowa mówiące o afirmacji stworzenia (por. LS 77) ${ }^{5}$, przytoczył wezwania pełne chwały i uwielbienia dla

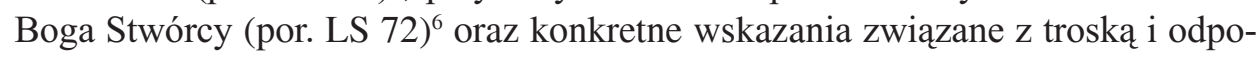
wiedzialnością za świat, zwłaszcza za los zwierząt (por. LS 68)7. Papież zwrócił

\footnotetext{
${ }^{2}$,Stworzył więc Bóg człowieka na swój obraz, na obraz Boży go stworzył: stworzył mężczyznę i niewiastę (Rdz 1,27)".

${ }^{3}$ „«Bądźcie płodni i rozmnażajcie się, abyście zaludnili ziemię i uczynili ją sobie poddaną; abyście panowali nad rybami morskimi, nad ptactwem powietrznym i nad wszystkimi zwierzętami pełzającymi po ziemi». [...] I stało się tak (Rdz 1,28-30). Pan Bóg wziął zatem człowieka i umieścił go w ogrodzie Eden, aby uprawiał go i doglądał (Rdz 2,15)".

${ }^{4}$ „«Nie wolno sprzedawać ziemi na zawsze, bo ziemia należy do Mnie, a wy jesteście u Mnie przybyszami i osadnikami» (Kpł 25,23)”.

${ }_{5}$ „Miłujesz bowiem wszystkie stworzenia, niczym się nie brzydzisz, co uczyniłeś, bo gdybyś miał coś w nienawiści, nie byłbyś tego uczynił (Mdr 11,24)”.

${ }^{6}$ „On rozpostarł ziemię nad wodami, bo Jego łaska na wieki (Ps 136,6). Chwalcie Go, słońce i księżycu, chwalcie Go, wszystkie gwiazdy świecące. Chwalcie Go, nieba najwyższe i wody, co są ponad niebem: niech imię Pana wychwalaja, On bowiem nakazał i zostały stworzone (Ps 148,3-5)".

${ }^{7}$, „UJeśli zobaczysz, że osioł twego brata albo wół jego upadł na drodze - nie odwrócisz się od nich, ale z nim razem je podniesiesz [...]. Jeśli napotkasz przed sobą na drodze, na drzewie lub na ziemi gniazdo ptaka z pisklętami lub jajkami wysiadywanymi przez matkę, nie zabierzesz matki z pisklętami» (Pwt 22,4.6). Podobnie odpoczynek siódmego dnia proponowany jest nie tylko dla ludzi, ale także «aby odpoczęły twój wół i osioł» (Wj 23,12)" - tamże, 68.
} 
uwagę również na fakt, że prawo do regularnego, czyli cotygodniowego odpoczynku, nakazywało powstrzymywanie się od pracy siódmego dnia, co dotyczyło nie tylko ludzi, ale obejmowało również świat zwierząt (por. LS 237) ${ }^{8}$.

Na obecność w życiu i nauczaniu Chrystusa przesłanek uzasadniających potrzebę i znaczenie ekologicznej duchowości Ojciec Święty wskazał w tekstach, które same w sobie są zachwytem Zbawiciela nad pięknem stworzenia i stanowią zachętę, by zawsze być wrażliwym na otaczające nas piękno (por. LS 97) ${ }^{9}$, mówią o trosce Boga o stworzenie (por. LS 96) ${ }^{10}$, jak również o panowaniu Chrystusa nad przyrodą (por. LS 98) ${ }^{11}$. Z Nowego Testamentu papież przypomniał słowa mówiące o podporządkowaniu Chrystusowi wszystkiego, co zostało stworzone (por. LS 99) ${ }^{12}$ oraz słowa budzące podziw nad dziełami Boga Stwórcy (por. LS 74) ${ }^{13}$.

W świetle powyższego biblijne podstawy duchowości ekologicznej, wskazane przez papieża Franciszka, można sprowadzić do siedmiu elementów: wielkiej godności każdej osoby ludzkiej, godności wynikającej ze stworzenia na obraz i podobieństwo Boże; oparcia ludzkiej egzystencji na ściśle powiązanych ze sobą relacjach z Bogiem, ludźmi i ziemią; troski oraz miłości Boga względem stworzonego świata; konieczności troski i odpowiedzialności człowieka za otaczający go świat, stanowiący własność Boga; licznych zachęt do uwielbiania Boga Stwórcy; prawa do cotygodniowego odpoczynku, które dotyczy także zwierząt; harmonii Jezusa ze stworzeniem i Jego panowania nad nimi. Tę papieską argumentację można uznać za działanie będące podaniem biblijnych przesłanek wskazujących na powiązania człowieka $\mathrm{z}$ otaczającym go światem, wypływające z woli Stwórcy oraz z życia i nauczania Chrystusa, jak również na wynikająca z powyższego powinność uwzględniania ich w osobistej i społecznej drodze prowadzącej do komunii z Bogiem.

\section{PRZESŁANKI TEOLOGICZNO-PRAKTYCZNE}

Oprócz argumentacji biblijnej papież Franciszek podał wiele innych powodów uzasadniających znaczenie przeżywania drogi prowadzącej do komunii 23,12).

${ }^{8}$,«Aby odpoczęły twój wół i osioł i odetchnęli syn twojej niewolnicy i cudzoziemiec» (Wj

${ }^{9}$, „Podnieście oczy i popatrzcie na pola, jak bieleją na żniwo» (J 4,35). «Królestwo niebieskie podobne jest do ziarnka gorczycy, które ktoś wziął i posiał na swej roli. Jest ono najmniejsze ze wszystkich nasion, lecz gdy wyrośnie, jest większe od innych jarzyn» (Mt 13,31-32)”.

${ }^{10}$, «Czyż nie sprzedają pięciu wróbli za dwa asy? A przecież żaden z nich nie jest zapomniany w oczach Bożych» (Łk 12,6); «Przypatrzcie się ptakom w powietrzu: nie sieją ani żną i nie zbierają do spichrzów, a Ojciec wasz niebieski je żywi» (Mt 6,26)”.

${ }^{11}$ „Kimże On jest, że nawet wichry i jezioro są Mu posłuszne? (Mt 8,27)”.

12 "Wszystko przez Niego i dla Niego zostało stworzone (Kol 1,16)”.

13 „Dzieła Twoje są wielkie i godne podziwu, Panie, Boże wszechwładny! Sprawiedliwe i wierne są Twoje drogi (Ap 15,3)". 
z Bogiem w klimacie duchowości ekologicznej. Niektóre z nich mają charakter teologiczny, inne z kolei bardziej praktyczny. Pierwszym teologicznym argumentem jest sam fakt stworzenia wszystkiego przez Boga, co sprawia, że „byty wszechświata, będąc stworzonymi przez tego samego Ojca, są zjednoczone niewidzialnymi więzami i tworzą rodzaj uniwersalnej rodziny (LS 89)". Ze względu na ścisłe połączenie człowieka ze światem wyginięcie jakiegoś gatunku można nawet traktować jako swoiste okaleczenie (por. LS 89; zob. Benedykt XVI, 2009, nr 14). Kolejny argument, tzw. trynitarny, wiąże się z prawdą o istnieniu Boga Trójedynego, czyli Ojca i Syna, i Ducha Świętego. Papież Franciszek zauważył, że człowiek „tym bardziej się uświęca, im bardziej wchodzi w relacje, przekraczając siebie, aby żyć w komunii z Bogiem, z innymi i ze wszystkimi stworzeniami (LS 240)”. W ten sposób „przyjmuje w swoim życiu ową dynamikę trynitarna, jaką Bóg w nim odcisnął od początku jego istnienia (LS 240)". Jednocześnie papież stwierdził, że kontemplowanie wielkości oraz piękna wszechświata nieuchronnie prowadzi do wysławiania całej Trójcy Świętej (por. LS 238). Innym teologicznym argumentem uzasadniającym potrzebę i wartość duchowości ekologicznej jest rzeczywistość istnienia sakramentów w Kościele, a szczególnie Eucharystii. Według Franciszka, sakramenty są niezwykłym, uprzywilejowanym sposobem pokazania, że natura przyjęta przez Boga, została przez Niego przemieniona i włączona $\mathrm{w}$ pośrednictwo życia nadprzyrodzonego (por. LS 235). Można uznać, że „woda, olej, ogień i kolory są przyjęte wraz z całą ich siłą symboliczną i włączają się w chwalenie Boga (LS 235)". W szczególny sposób jest to widoczne w sakramencie Eucharystii: Syn Boży, który stał się człowiekiem, dał siebie samego za pokarm, co jest aktem wręcz kosmicznej miłości (por. LS 236). Z tego względu Eucharystia, która jednoczy niebo i ziemię, obejmuje oraz przenika wszystko, całe stworzenie. W tym kontekście papież zauważa, że „Eucharystia jest także źródłem światła i motywacji dla naszych niepokojów o środowisko i ukierunkowuje nas, byśmy byli opiekunami całego stworzenia (LS 236)".

Poza wymienionymi wyżej argumentami teologicznymi Franciszek przytoczył przykłady z życia kilku świętych. Przede wszystkim przywołał postać św. Franciszka z Asyżu, który „«rozważając początek wszystkich stworzeń, ożywiał coraz bardziej swą pobożność i wszystkie stworzenia, choćby najmniejsze, nazywał braćmi lub siostrami, ponieważ wiedział, że razem $\mathrm{z}$ nim pochodzą $\mathrm{z}$ tego jednego Źródła» (LS 11)" (zob. Bonawentura św., 2005, 6). Papież zauważył również, że św. Franciszek, będąc mistykiem, potrafił żyć z prostotą i we wspaniałej harmonii zarówno z ludźmi, jak i z naturą czy z samym sobą (por. LS 10). Obok św. Franciszka Ojciec Święty przypomniał św. Jana od Krzyża, mistyka, który doświadczał ,wewnętrznej więzi, jaka istnieje między Bogiem a wszystkimi bytami (LS 234)". Dzięki temu mógł on oznajmić, że Bóg jest wszystkim dla niego (por. LS 234). Papież przywołał także postać św. Teresy z Lisieux, która, 
jak stwierdził, czyniła wszystko, aby nie zaniedbywać okazji do dobrego słowa, uśmiechu, małego gestu, który wnosiłby w życie pokój i służył przyjaźni (por. LS 230). W tym kontekście Ojciec Święty podkreślił, że ekologia integralna składa się w swojej wymowie również z wielu prostych gestów, które przełamują logikę przemocy, wyzysku czy egoizmu (por. LS 230). Kolejną osobą przywołaną przez papieża jest św. Józef. Może on nauczyć troski o świat i pobudzać do wielkodusznej pracy z taką czułością, aby chronić świat, który Bóg powierzył ludziom (por. LS 242). Papież Franciszek zauważył, że w uwielbionym ciele Matki Najświętszej część stworzenia osiagnęła już pełnię piękna razem ze zmartwychwstałym Chrystusem (por. LS 241). Matka Boża jest dla papieża również Tą która - tak jak kiedyś troszczyła się o Jezusa - z miłością troszczy się o... poraniony świat (por. LS 241).

Kolejną przesłanką która podkreśla wagę i potrzebę mówienia o duchowości ekologicznej jest zatroskanie o miłość braterska. Zdaniem papieża, świadoma troska o przyrodę stanowi część takiego stylu życia, który odznacza się zdolnością do życia razem i w komunii (por. LS 228). Franciszek stwierdził wprost, że „kochamy i akceptujemy wiatr, słońce lub chmury, pomimo że nie podlegają naszej kontroli”" (LS 228). Z tego też względu stwierdził, że można mówić o powszechnym braterstwie (por. LS 228). Pragnienie wewnętrznej radości i pokoju również winno inspirować do troski o środowisko oraz dobro wspólne, gdyż, jeśli są one przeżywane autentycznie, odzwierciedlają zrównoważony styl życia w połączeniu ze zdolnością do zadziwienia, a ta z kolei prowadzi do głębi życia (por. LS 225). Ostatnim z argumentów przemawiających za wyborem duchowości ekologicznej jako wartości i potrzeby jest kryzys ekologiczny, który - zdaniem papieża - będzie „wezwaniem do głębokiego wewnętrznego nawrócenia (LS 217)” (por. Benedykt XVI, 2005). Według Franciszka, życie powołaniem, aby być obrońcą dzieła Bożego, należy do istoty życia uczciwego, nie zaś opcjonalnym albo drugorzędnym elementem doświadczenia chrześcijańskiego (por. LS 217).

W świetle powyższych rozważań teologiczno-praktyczne podstawy duchowości ekologicznej - wskazane przez papieża Franciszka - można sprowadzić do siedmiu istotnych punktów: stworzenia wszystkiego przez Boga; istnienia Trójcy Świętej; specyfiki sakramentów, a zwłaszcza sakramentu Eucharystii; przykładów z życia wybranych świętych; troski o braterską miłość; pragnienia radości i pokoju oraz doświadczania kryzysu ekologicznego.

\section{OWOCE I KONSEKWENCJE DUCHOWOŚCI EKOLOGICZNEJ}

Przyjęcie duchowości ekologicznej, zdaniem papieża Franciszka, oznacza w praktyce nowy styl życia, który implikuje różnorodne postawy i działania. Pierwszym skutkiem życia według duchowości ekologicznej jest zatamowanie negatywnych tendencji, które są obecne we współczesnym świecie. Papież w tym 
kontekście wskazuje na różnorakie formy zbiorowego egoizmu, wynikające z poczucia tymczasowości (por. LS 204) oraz na silną potrzebę nabywania rzeczy materialnych. Znamienna jest teza, postawiona przez Franciszka: im bardziej serce danej osoby jest puste, tym bardziej potrzebuje ona rzeczy, które mogłaby nabyć, posiadać i konsumować (por. LS 204). Ojciec Święty zauważa także istniejąca w świecie obsesję na tle konsumpcyjnego stylu życia, która może prowokować jedynie do stosowania przemocy i wzajemnego zniszczenia (por. LS 204). Życie według duchowości ekologicznej wyzwala i z tej obsesji.

Obok minimalizowania negatywnych tendencji istniejących we współczesnym świecie duchowość ekologiczna sprzyja kształtowaniu się pozytywnych postaw, zarówno zewnętrznych, jak i wewnętrznych. Wśród tych zewnętrznych papież Franciszek, odwołując się do Karty Ziemi ONZ, podkreślił „przebudzenie nowego szacunku do życia, mocnego postanowienia osiagnięcia równowagi, przyspieszenia walki o sprawiedliwość i pokój oraz radosnej celebracji życia" (Organizacja Narodów Zjednoczonych, 2000, Karta Ziemi). Wskazał także na zaangażowanie się w wywieranie zdrowej presji na tych, którzy sprawują władzę polityczna, gospodarczą i społeczną oraz wpływanie na to, by nie kupowano pewnych produktów czy nawet zmieniano funkcjonowanie przedsiębiorstw (LS 206). Papież przypomniał słowa swojego poprzednika Benedykta XVI: „Kupno jest zawsze aktem moralnym, nie tylko ekonomicznym" (LS 206) (Benedykt XVI, 2009, Rzym, nr 66). Podkreślił, że zagadnienie degradacji środowiska wiąże się z potrzebą zmiany zachowań każdego człowieka (por. LS 206). Życie według ekologicznej duchowości prowadzi do pozytywnej zmiany zachowań jednostek i społeczeństw. Papież Franciszek do pozytywnych zmian zaliczył: uwzględnienie wartości pracy bez koncentrowania się na szybkim uzyskaniu dochodu (por. LS 124 i 128), zaangażowanie na rzecz dobra wspólnego i dokonywanie solidarnych wyborów uwzględniających „opcję preferencyjną na rzecz ubogich" (por. LS 158), podjęcie obowiązku troszczenia się o środowisko przez małe, ale podejmowane codziennie działania (por. LS 211), a także wykonywanie prostych, codziennych gestów, przełamujących logikę przemocy, wyzysku czy egoizmu (por. LS 230).

Wiele uwagi Ojciec Święty poświęcił pozytywnym, wewnętrznym konsekwencjom życia według duchowości ekologicznej. Takie postępowanie, jak zauważył, prowadzi do zrozumienia, że wyższość człowieka wierzącego nad innymi ludźmi nakłada na niego poważną odpowiedzialność wypływającą z wiary (por. LS 220). Podkreślił także, że sprzyja podziwianiu świata od wewnątrz, rodząc w człowieku miłującą świadomość faktu tworzenia $\mathrm{z}$ innymi stworzeniami powszechnej komunii (por. LS 220). Duchowość ekologiczna pozwala żyć powołaniem, aby być obrońcą dzieła Bożego (por. LS 217). Franciszek zauważył również, że taka duchowość prowadzi do rozwinięcia nowej zdolności wychodzenia ku innym, a także przyjęcia postawy autotranscendencji, która umożliwia 
troskę o bliźnich i środowisko naturalne oraz ocenę skutku każdego działania i każdej osobistej decyzji (por. LS 207). Kolejną konsekwencją życia duchowością ekologiczną jest rozwijanie kreatywności i wzrost entuzjazmu oraz zaangażowanie się $\mathrm{w}$ działania mające pomóc $\mathrm{w}$ rozwiązywaniu dramatów świata w duchu ofiarowania siebie Bogu na „ofiarę żywa, świętą, Bogu przyjemną” (Rz 12,1; por. LS 220). Zdaniem Ojca Świętego, duchowość ekologiczna motywuje do troski o dalsze doskonalenie się w cnotach, które samo w sobie jest jednocześnie warunkiem zaangażowania się w działalność ekologiczną (por. LS 211), owocuje postawą wdzięczności i bezinteresowności (por. LS 220), gotowością do podejmowania bezinteresownych wyrzeczeń (por. LS 220), a także sprzyja podejmowaniu odpowiedzialnej ascezy oraz kontrolowaniu i wychowywaniu siebie nawzajem (por. LS 214). Franciszek zwrócił również uwagę na fakt, że życie duchowością ekologiczną głęboko motywuje do kierowania się miłością w działalności ekologicznej, a jako przykład papież podał ponowną bardzo głęboko umotywowaną utylizację różnych rzeczy (por. LS 211).

Podsumowując dotychczasowe rozważania, nowy styl życia związany z przyjęciem duchowości ekologicznej można określić jako tendencję, która charakteryzuje się: sprzeciwem wobec zbiorowego egoizmu, potrzeby nabywania rzeczy i obsesji na tle konsumpcyjnego stylu życia; świadomością odpowiedzialności za świat; życiem zgodnym z powołaniem, by być obrońcą dzieła Bożego; podziwianiem świata od wewnątrz; większą miłością bliźniego; rozwijaniem kreatywności i entuzjazmu; motywacją do doskonalenia się w cnotach, wdzięcznością i bezinteresownością; odpowiedzialną ascezą, szacunkiem dla życia; różnorakim zaangażowaniem w sprawy ekologii; przedkładaniem pracy nad pochodzący z niej zysk, zaangażowaniem się na rzecz dobra wspólnego.

\section{ZNACZENIE DUCHOWOŚCI EKOLOGICZNEJ DLA ŻYCIA I BEZPIECZEŃSTWA CZŁOWIEKA}

Przeprowadzona analiza encykliki Laudato si' upoważnia do postawienia pewnych tez i wyciagnięcia wniosków.

1. Życie według duchowości ekologicznej jest wielkim dobrem dla człowieka i wpływa pozytywnie na jego bezpieczeństwo rozumiane w szerokim kontekście społecznej egzystencji.

2. Duchowość ekologiczna rodzi dodatkowe inspiracje oraz motywuje do dbałości i troski o własny rozwój duchowy, o swoje zbawienie, a zatem pomnaża miłość człowieka do Boga. Kierowanie się nią wymaga pogłębionej refleksji duchowej i życia w przyjaźni z Bogiem.

3. Codzienność przeżywana ze świadomością przyjęcia wszystkich konsekwencji wynikających ze spotkania człowieka z Jezusem i ich odzwier- 
ciedlenia $\mathrm{w}$ relacjach $\mathrm{z}$ otaczającym go światem powoduje wzrost wrażliwości na potrzeby innych, szczególnie ubogich i wykluczonych, co owocuje większą troską o bliźnich, zatem pomnaża miłość do bliźnich.

4. Duchowość ekologiczna sprzyja osiągnięciu pełniejszej wewnętrznej harmonii z samym sobą, czyli pomaga realizować zdrową miłość do siebie samego, co jest koniecznym warunkiem wzrastania w miłości do drugiego człowieka.

5. Życie zgodne z wymogami duchowości ekologicznej sprawia, że człowiek funkcjonuje na co dzień w większej harmonii z przyrodą i całym otaczającym go światem, co z kolei pomaga mu kochać Boga, bliźnich i siebie samego, a jednocześnie czyni jego życie bardziej spokojnym i zrównoważonym.

Podsumowując znaczenie duchowości ekologicznej dla dobra człowieka, który według niej żyje, należy zauważyć, że przyjęcie takiego stylu życia sprzyja zdrowiu zarówno duszy, jak i ciała. Ma zatem wartość nie tylko doczesną, ale sięgającą o wiele głębiej: dotyka wymiaru duchowego, nadprzyrodzonego, wiecznego.

\begin{abstract}
Ecological spirituality is - strongly taking into account and stressing the relationship with the world - the realization of communion of a man with God. A Christian characterized by ecological spirituality, in his pursuit of holiness, will focus on the consequences of man's encounter with Jesus in relations with the surrounding world. Pope Francis dedicated the last, sixth chapter of the Encyclical Laudato si to ecological spirituality.

The author of the presentation has divided the whole issue into two parts. In the first one he pointed to the biblical, theological and practical motives for the need of ecological spirituality, in the second one he presented its fruits and consequences. In the summary of the research he emphasized the importance of ecological spirituality for the man's sake and safety. The study carried out entitles the author to conclude that the adoption of a lifestyle that results from ecological spirituality, promotes health of both soul and body. Such a way of life has therefore not only a temporal value, but also it reaches much deeper: it opens the life of a man to a perspective of supernatural, eternal life.
\end{abstract}

\title{
Keywords
}

spirituality, ecology, creation, the Bible, love

\section{BIBLIOGRAFIA}

Franciszek, Encyklika Laudato si', Libreria Editrice Vaticana, Rzym 2015.

Benedykt XVI, Encyklika Caritas in veritate, Libreria Editrice Vaticana, Rzym 2009.

Benedykt XVI, Homilia podczas Mszy św. z okazji inauguracji pontyfikatu, AAS vol. 97 (2005). 
DUCHOWOŚĆ EKOLOGICZNA W ŚWIETLE LAUDATO SI’ PAPIEŻA FRANCISZKA 111

Bonawentura, Życiorys większy św. Franciszka, w: Źródła franciszkańskie, Wydawnictwo „Bratni Zew”, Kraków 2005.

Gogola J., Teologia komunii z Bogiem, Wydawnictwo Karmelitów Bosych, Kraków 2003.

Hadryś J., A B C... życia duchowego w pytaniach i odpowiedziach, Wydawnictwo Bonami, Poznań 2009.

Organizacja Narodów Zjednoczonych (2000), Karta Ziemi, http://kartaziemi.wordpress. com/tekst-karty-2/ [dostęp: 16.09.2016].

Jacek Hadryś - ur. w 1962 roku w Krotoszynie, kapłan archidiecezji poznańskiej, dr hab. teologii, prof. UAM, kierownik Zakładu Teologii Moralnej, Duchowości i Katolickiej Nauki Społecznej WT UAM w Poznaniu. 